\title{
EUROPEAN UNION-UKRAINE ASSOCIATION AGREEMENT: CHALLENGES AND PROSPECTS FOR COOPERATION
}

\author{
Olena Durman \\ Kherson National Technical University, Ukraine \\ Mykola Durman \\ Kherson National Technical University, Ukraine \\ Tatyana Mazievich \\ Kherson State Agrarian and Economic University, Ukraine \\ Oksana Zhiliaieva \\ Taras Shevchenko National University of Kyiv, Ukraine \\ Kherson State University, Ukraine \\ Svitlana Arkhypenko \\ Kryvyi Rih National University, Ukraine
}

\begin{abstract}
The purpose of this study was to substantiate the features and determine an effective strategy for Ukraine's Eurointegration. Using a theoretical analysis of reports on the fulfilment of the terms of the European Union (EU)-Ukraine Association Agreement" (AA), we identified the problems and destructive factors of the European integration for Ukraine. The Graph Theory helped to prioritize these problems in the context of implementing the AA's tasks. Constructed neural models and elasticity coefficients provided a quantitative assessment of the adequate performance of strategic functions within the framework of the AA for Ukraine have been carried out. The priority of conduction tasks argued for the importance of implementing a strategy of moderate adaptation for Ukraine to increase the positive effect of cooperation with the EU and sustainable development of the country. .
\end{abstract}

Keywords: European Union-Ukraine Association Agreement, eurointegration, adaptation strategy, cooperation, sustainable socio-economic development.

DOI: http://dx.doi.org/10.15549/jeecar.v8i3.780

\section{INTRODUCTION}

One of the fundamental modern priorities of the state policy of Ukraine enshrined in the
Constitution (The Constitution of Ukraine, 2020) is to achieve full membership of the country in the European Union (EU). As the results of numerous studies and randomized polls show, 
more than $60 \%$ of citizens support Ukraine's accession to the EU, and the number of supporters of integration is growing every year (Ukrainian truth, 2021a). Ukraine is only at the initial stage of the integration process, namely associated interaction, which began in 2014, when Ukraine and the European Union signed the European Union-Ukraine Association Agreement (AA). Ukraine is a priority partner for the EU (Association Agreement between the European Union and Ukraine. (2021).

Since the adoption of the AA, Ukraine has made significant progress in reforming socio-economic and political life. The most important achievements are the reform of decentralization (Eurointegration portal, 2021). Accordingly, the united territorial communities collected 5-122\% more local taxes than before the unification, the share of expenses on retaining local governments in the structure of local budget expenditures decreased by $12 \%$, the percentage of labor costs by $4 \%$, and development expenses increased local infrastructure by $46-569 \%$ (Harus \& Nivyevskyi, 2020). The implemented measures which aimed to create a comprehensive free trade zone contributed to an increase in exports of Ukrainian goods to the EU by $60 \%$ over 2014 2020. During this period, the number of enterprises whose production technologies meet European standards and have the right to export products to the EU has doubled (Eurointegration portal, 2021).

Today, there is practically no sphere of Ukaraine socio-economic development that has not been covered by the European integration processes. The list of issues on the Ukraine-EU agenda is constantly expanding. But along with significant achievements, many problems remain that hinder the development of European integration.

Justice, freedom, security, and human rights. Corruption is the most significant problem for Ukraine (European Commission, 2020). In 2020, the country occupied the 117th position (out of 179 countries represented in the rating) according to the Corruption Perceptions Index (Transparency International, 2020), even though the Supreme Anti-Corruption Court operates in Ukraine and laws on the resumption of the activities of the National Agency for the Prevention of Corruption and many other regulations aimed at combating corruption have been adopted.

According to Government portal (2021), the fight against corruption refers to the progress in implementing the Agreement on Justice, Freedom, Security, and Human Rights (JUST). Corruption destabilizes such main areas of socioeconomic development as "taxation" (TAX), "public procurement" (PUR), "financial cooperation and the fight against fraud" (FRAUD), "consumer protection" (CONS). The most corrupt industries and institutions in Ukraine in 2020 were the justice, law enforcement, and customs systems, the taxation system, the construction industry, agriculture, energy, public finance, public procurement, and transport infrastructure (Schemes against Independence, 2020). Corruption in the following especially restrained development: "customs issues" (CUST); "agriculture" (AGR),|; "energy" (ENER); "public financial management" (PUB.FIN); "Transport, transport infrastructure, postal and courier services" (TRANS); and personal data protection when using artificial intelligence (AI), which affects the efficiency of FA in the field of intellectual property (INTEL).

Political dialogue, national security, and defense. The problematic area of AA implementation is Political Dialogue, National Security and Defense (POLIT), despite high overall progress in the implementation of the SA (89\% of the responsibilities undertaken by Ukraine until 2024) (Eurointegration portal, 2021). The significant achievements were the removal of parliamentary immunity, public administration reform, decentralization, legislative work to reform the electoral system, and the national security system by EU and NATO standards. Along with these achievements, the territorial integrity and sovereignty of the state, national security in connection with the military conflict in the east of Ukraine, and the annexation of Crimea remain under threat. First of all, the destabilizing influence of this factor affects freedom, security, and observance of human rights (JUST). As a result, the Ukrainian economy has suffered greatly. The metallurgical, machine-building industries and the energy sector (ENER) were particularly affected under the AA, and losses were incurred from the destruction of transport infrastructure (TRANS) 
(European Commission, 2020). Budget expenditures increased, but the ability to control the intended use of money decreased, which negatively affected the public financial management system (PUB.FIN). Also, military conflict has significantly undermined the country's financial system (FIN).

The growth in fuel imports, caused by the problems of the energy sector, led to a significant increase in energy prices not only for the economy but also for the people, which became an obstacle to the development of Eurointegration in the following areas:

Energy Efficiency and Housing and Utilities (UTIL);

- "Humanitarian policy" (HUM) as a consequence of the destruction of the Crimean Tatar identity and cultural heritage;

- "Social policy and labor relations" (SOC) as a result of job cuts, loss of housing, lack of social benefits, and the need to relocate to other regions;

- "Civil health" (HEAL) from loss of life due to armed conflict (European Commission, 2020).

Government procurements. In the area of public procurement, progress in the implementation of the AA consists of:

Legislative support and practical implementation of the electronic procurement system ProZorro;

Opening full access to the Ukrainian public procurement market for EU companies.

But this progress gives rise to discrimination against foreign companies' residents in countries that are not members of the EU (European Commission, 2020). In addition, the Tender Committee of the Ministry of Health was established in 2019. Previous experience of the functioning of similar bodies allows us to assert their corruption and create a particular circle of interests for lobbying (JUST) (European Commission, 2020). This negatively affects businesses that depend on public procurement, as well as the provision of public services, such as trade (TRADE), housing and utilities (UTIL), transport, transport infrastructure (TRANS), and medicine (HEAL) (YouControl, 2018), the reform of which is envisaged by the AA.
Energy. The reform progress consists of: stimulating the development of renewable energy; stage-by-stage synchronization of the energy system with the European ENTSO-E network and with the operation of the European gas market; legislative regulation of radiation protection issues; and opening a wholesale electricity market aimed at optimizing logistics processes by eliminating intermediary enterprises in the market (Government portal, 2021).

In practice, the stimulation of renewable energy development and the scheme of creating a functioning single market aims to lobby the interests of "green" producers. The "green" producers sell their energy to solvent buyers, while traditional producers, which produce cheaper energy and in large volumes, sell them to the people - to fewer solvent buyers (Zanuda, 2020). As a result, excess profits are created for one category of producers, whose interests are lobbied at the state level, but significant indebtedness for another class, and, as a result:

- Debts in the system of housing and communal services (UTIL) are increasing,

- Efficiency of public finance management (PUB.FIN) is declining ;

Political tension among the participants of the wholesale market (POLIT) is growing.

Public finance management. In 2021, the Budget Declaration was adopted for the first time on implementing medium-term budget planning to ensure the transparency of fiscal policy and the sustainability of public finances. At the same time, though, the estimates of the Ministry of Finance and the Ministry of Economy regarding the forecast of macroeconomic indicators that should underlie the declaration are inconsistent. In addition, the budget process did not take into account changes to the Tax Code in the statement for 2022-2024, which significantly affects the tax revenues.

The deficiencies in the approval of the Budget Declaration led to the ineffectiveness of the Organization of Information Exchange (STAT) and the unreasonableness of the budget planning indicators. This negates the effectiveness of government funding of reforms by the $\mathrm{AA}$, and primarily concerns the areas of the social sphere: 
"education, youth, training" (EDUC); "humanitarian policy" (HUM); "science, technology and innovation, space" (SCIEN); "social policy and labor relations" (SOC); "Environment and civil protection" (ENVIR); "sanitary and phytosanitary measures" (SANIT); and "civil health" (HEAL) as well as opportunities for state support for entrepreneurship (ENT), which is especially relevant under the COVID-19 pandemic.

Statistics and information exchange. Despite significant progress in reforming the statistical information system throughout the AA $(68 \%$ of the commitments made for the period up to 2024), there are problems associated with its functioning - duplication of the same statistical indicators and not reporting from the ministries of collecting statistical information in Ukraine, which is contrary to the UN Model Law (Generic Law on Official Statistics for Eastern Europe, Caucasus, and Central Asia, 2017). This has a destructive effect on the successful implementation of the AA in the areas of "education, youth, training" (EDUC), "science, technology and innovation, space" (SCIEN), and, above, "public financial management" (PUB.FIN).

Technical trade barriers. The problem in implementing this direction is the ban on the export of raw timber, which does not comply with the AA (Eurointegration portal, 2021). This prohibition creates restrictions on public financial management (PUB.FIN) and is an environmental protection instrument (ENVIR).

Transport, transport infrastructure, postal and courier services. Progress in implementing the AA is adopting many laws to adapt Ukrainian legislation to the EU (Government portal, 2021). But given the increase in the number of road accidents in Ukraine and significant emissions of pollutants, the problem of the implementation of CA and the achievement of sustainable development goals is the reform of the procedure for mandatory technical control of vehicles, which has a detrimental effect on the environment (ENVIR) and the health of citizens (HEAL).

Intellectual property. Intellectual property has one of the lowest performance levels, $54 \%$ for the period 2014-2020 (Eurointegration portal, 2021), due to the lack of legislative regulation of AI, the absence of copyright law using AI, etc. This is destructive to the development of science, technology, and innovation (SCIEN).

Taxation. Overall progress has been achieved in the amount of $60 \%$ of the CA implementation plan until 2024. Improvement concerns the State Tax Service reform, the State Customs Service of Ukraine, and amendments to the Customs Code. The problematic aspects are the VAT refund procedure, the improvement of which will contribute to increasing the efficiency of entrepreneurship (ENT) and public finances (PUB.FIN), the effectiveness of combating fraud (FRAUD) (Eurointegration portal, 2021).

The above main characteristics of the adaptation process in Ukraine allow us to conclude that the implementation of the AA is not a "process for a process" but is subordinated to the strategic goal of the country's integration into the EU. Nevertheless, the 10-year AA of Ukraine with the European Union in the first five years of operation was fulfilled by $41.6 \%$ (Government portal, 2021). The Action Plan program for implementing the AA in 2020 fulfilled its obligations by $30 \%$. This is the lowest indicator for all the years of implementation of the agreement (Ukrainian truth, 2021b). The current situation is due to the lack of clear priorities for the effectiveness of implementing AA directions and the presence of many accompanying risks for Ukraine from integration into the EU (Babenko, Biletska \& Pelyak, 2019). Therefore, this study aims to substantiate the features of the influence of SA on the sustainable development of Ukraine. In the study, we did a hierarchical structuring of the problems associated with the implementation of the AA and established their priority. A quantitative assessment of the prospects for sustainable development resulting from solving the priority problems of the performance of the AA has been carried out.

\section{LITERATURE REVIEW}

Many scholars adhere to the point of view that countries belonging to the post-Soviet group of countries, and which have developed economic ties with the EU over the past decades have not received any positive effects from those economic ties (Kachala \& Kovalchuk, 2015). The reasons are, first, that full trade liberalization and regulatory integration with the $\mathrm{EU}$, as envisaged 
by the AA, can lead to costs from internal actors not compensated by appropriate EU assistance. The AA assumes that significant structural changes will be made in the Ukrainian economy, provoking losses for southeastern Ukraine as an industrial region, yet the projected growth gains in agriculture and information technology are unlikely to offset losses from the downsizing of inefficient heavy industries (Spiliopoulos, 2014). This could lead to more active opposition to economic reforms and renew long-standing regional divisions. In addition, the $\mathrm{EU}$, for the entire period of the AA, did not provide Ukraine with significant material assistance and is not ready to offer it in the future (Government portal, 2021). Initiatives to restructure the Ukrainian economy have not been accompanied by a donation to local industrial enterprises, which is common practice for EU participants (Babenko, Biletska \& Pelyak, 2019).

But on the other hand, after Ukraine gained independence, the EU allocated more than €3.3 billion to Ukraine in non-refundable funds (technical assistance, supplies, works, and grants). In addition, the European Union has allocated more than $€ 3$ billion in loans (Government portal, 2021). Also, Ukraine was given an individual assistance package during the COVID-19 pandemic for over $€ 190$ million (European Commission, 2021).

There are doubts about Ukraine's ability to solve the tasks put forward by the AA because the current EU regulatory framework stimulates the formation of a single market only for developed markets (Pisarovi'c et al., 2021). Therefore, the limited administrative capacity, low professional potential of the top political leadership, and weak legal and economic systems in Ukraine are the main destructive factors for implementing the provisions of the AA and the possibility of integration (Poshedin, Palamarchuk \& Gaievska, 2020). In contrast, for introducing new standards to occur due to a controlled and controlled process, the AA provides for Ukraine a certain amount of authority to make decisions about which industries should be given priority. AA also provides an extended period during which changes should be implemented (Government portal, 2021). Therefore, most scholars believe that the country will receive significantly more positive effects from EU membership (Fig. 1) (Government portal, 2021; Babenko, Biletska \& Pelyak, 2019; Durman et al., 2021; Poshedin, Palamarchuk \& Gaievska, 2020)

\begin{tabular}{|l|l|}
\hline $\begin{array}{l}\text { Improving access of Ukrainian goods and } \\
\text { services to the EU market }\end{array}$ \\
\hline $\begin{array}{l}\text { Increase in the volume of Western } \\
\text { investments in the Ukrainian economy } \\
\text { Increasing the volume of bilateral trade }\end{array}$
\end{tabular}

Figure 1: Positive and negative aspects of Ukraine's integration into the EU

Source: Authors' finding

An equally important point actively discussed among scientists is the effectiveness of Ukraine's integration into the EU, which should directly determine the priorities in the implementation of the strategic tasks of the AA. Conceptually, there are three main approaches to adaptation - minimum, moderate, and maximum. A nonsystemic nature characterizes minimal integration; that is, there is a clear need to satisfy the opportunistic requests of the parties that have developed at a given time (Marchak \& Markuts, 2021). The strategy of moderate 
integration, based on the vision of the European Commission on the prospects of relations with its neighbors, including Ukraine, involves creating free trade with the EU and the spread of some other advantages of the EU internal market for Ukraine (Shevchuk, 2021). Maximum adaptation is fundamentally new for the Ukrainian adaptation process and presupposes full membership in the EU (Kuzmak, Kuzmak \& Pohrishchuk, 2021). Depending on the chosen adaptation strategy for the country's sustainable development, the effects can have a different nature, depending on Ukraine's pursued goals, institutional capacities, and the level of socioeconomic development of the country.

\section{METHODOLOGY}

The primary task of the study was to determine the priority problems of the implementation of the AA using the reports of the Cabinet of Ministers of Ukraine (Government portal, 2021) and the European Commission (2020) on the performance of the AA for 2014-2020 in the context of 24 directions: Energy (ENER); justice, freedom, security and human rights (JUST); technical barriers to trade (TRADE); entrepreneurship (ENT); Political Dialogue, National Security and Defense (POLIT); taxation (TAX); education, youth, learning (EDUC); humanitarian policy (HUM); agriculture (AGR); Science, Technology and Innovation, Space (SCIEN); financial sector (FIN); public procurement (PUR); social policy and labor relations (SOC); statistics and information exchange (STAT); transport, transport infrastructure, postal and courier services (TRANS); energy efficiency and housing and communal services (UTIL); public finance management (PUB.FIN); environment and civil protection (ENVIR); sanitary and phytosanitary measures (SANIT); consumer protection (CONS); financial cooperation and anti-fraud (FRAUD); civil health (HEAL); customs issues (CUST); intellectual property (INTEL).

The Graph Theory was used to prioritize the implementation problems of AA tasks. The indicated directions of the AA implementation were the vertices of a directed graph built to prioritize problems. Arcs of the graph - the direction of influence between the vertices, were established based on theoretical analysis. In this case, the direction of the graph arc was defined as the totality of the impact of all problems within every direction of the AA implementation. Priority problems were understood as priority problems without the solution of which the successful implementation of the AA is not possible. With the help of neural networks, the modeling of the prospects for sustainable development of Ukraine was carried out, taking into account the solution of priority problems that formed the 1st level of the hierarchy. AA is focused on achieving sustainable development goals (Government portal, 2021). The dependent variables of the models were the following indicators: GDP per capita, expressed in thousands of US dollars; The Legatum Prosperity Index; the Human Development Index (as indicators of socio-economic development); and the Environmental Performance Index (as an indicator of environmental development), which reflects the concept of sustainable development (Kuzmak, Kuzmak \& Pohrishchuk, 2021).

When using the graph method (as vertices) and modeling using the prospects for the sustainable development of countries (as independent variables), not specific problems but their totality within each area according to the Reports on the implementation of the AA by Ukraine (Government portal, 2021) was revealed. The model's independent variables were the indicators of the overall progress in fulfilling obligations in the areas that formed the 1 st level of the hierarchy. General progress is understood as the proportion of the fulfillment of the commitments undertaken by Ukraine on the AA for the period up to 2024 , within each direction, as of the date of the analysis since the beginning of the AA action (June 2014) (Government portal, 2021). Achieving the Sustainable Development Goals depends not only on management efficiency but also on the availability of funding, which, according to (Razumovskaia et al., 2020), is a fundamental factor in ensuring sustainable development. Therefore, another group of independent variables is represented by the introductory growth rates of financing volumes: public expenditures in the areas of financing $(\mathrm{E})$; capital investment (CI); foreign direct investment (FDI); and financing of the implementation of the CA by the EU (F). Growth rates are calculated based on financing volumes expressed in USD relative to 2005 . When 
calculating the $\mathrm{F}$ indicator, 2015 was used as a comparison base.

The study used multilayer perceptron neural networks and the backpropagation method to determine the weights of the neural network synapses (Jin et al., 2020):

$y=f(\mathrm{Ag}$, Fin $)=f\left(W^{(n-1)} \cdot H^{(n-1)}+B^{(n-1)}\right)$

$\mathrm{Ag}=\left\{P\left(\mathrm{Ag}_{i}\right)=R\left(\mathrm{Ag}_{i}\right) \cap P\left(\mathrm{Ag}_{i}\right)\right\}$

where $y-a$ dependent variable that corresponds to indicators of sustainable development (GDP per capita, The Legatum Prosperity Index, Human Development Index, Environmental Performance Index);

$\mathrm{Ag}$, Fin - independent variables;

Fin - indicators of the dynamics of financing $(E$, CI, FDI, F);

$\mathrm{Ag}$ - indicators of progress in Ukraine's fulfillment of obligations by AA in areas forming the 1 st level of the hierarchy of $A A$ implementation problems;

$P\left(A g_{i}\right)$ - a subset of predecessor vertices from which there is a path along the directed graph leading to the vertex $\mathrm{Ag}_{\mathrm{i}}$;

$R\left(A g_{i}\right)$ - a subset of reach vertices - vertices to which, according to the directed graph, there is a path from the vertex $\mathrm{Ag}_{\mathrm{i}}$;

$W$ - neural network synapse weights vector;

$H$ - output pulse vector;

$B$ - noise vector

To build neural models in Statistica 12.0., we used annual data for 2005-2020. In models where GDP per capita and the Human Development Index acted as dependent variables, 1993-2020 was used; 1993 was used as the basis for calculating the growth rates of financing volumes.

\section{RESULTS}

Based on the described interrelationships between the problems of AA implementation, a directed graph was constructed (Fig. 2), and the levels of the hierarchy of issues were determined.

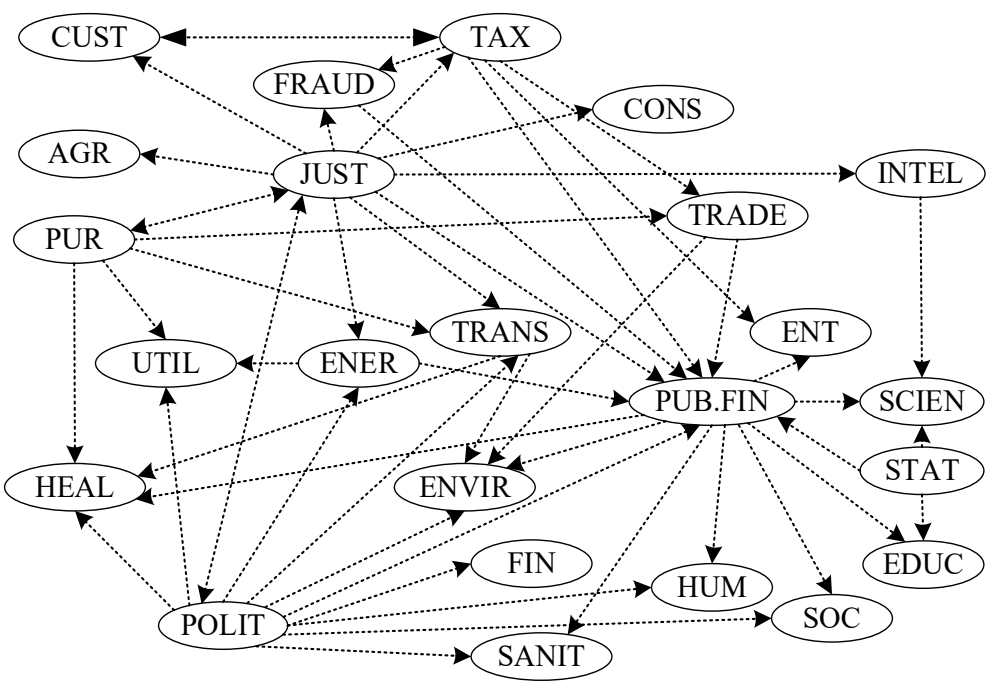

Hierarchy levels of issues

\begin{tabular}{|c|c|}
\hline $\begin{array}{l}\text { 5th level of } \\
\text { hierarchy }\end{array}$ & $\begin{array}{l}\text { Issues: ENT, } \\
\text { EDUC, HUM, SCIEN, } \\
\text { SOC, ENVIR, SANIT, } \\
\text { HEAL }\end{array}$ \\
\hline $\begin{array}{l}\text { 4th level of } \\
\text { hierarchy }\end{array}$ & Issues: PUB.FIN \\
\hline $\begin{array}{l}\text { 3rd level of } \\
\text { hierarchy }\end{array}$ & $\begin{array}{l}\text { Issues: TRADE, } \\
\text { UTIL, FRAUD, } \\
\text { CUST }\end{array}$ \\
\hline $\begin{array}{l}\text { 2nd level of } \\
\text { hierarchy }\end{array}$ & $\begin{array}{l}\text { Issues: ENER, } \\
\text { TAX, AGR, FIN, } \\
\text { STAT, TRANS, } \\
\text { CONS, INTEL }\end{array}$ \\
\hline $\begin{array}{l}\text { 1st level of } \\
\text { hierarchy }\end{array}$ & $\begin{array}{l}\text { Issues: } \\
\text { POLI] }\end{array}$ \\
\hline
\end{tabular}

Figure 2: A hierarchical model of the problems of successful implementation of the AA by Ukraine Source: Authors' finding

The 1st level of the hierarchy was formed by problems that hinder the implementation of the AA in the areas of "justice, freedom, security and human rights" (JUST), "political dialogue, national security and defense" (POLIT), and "public procurement" (PUR). 
Table 1: Characteristics of neural models of the impact of the progress of AA implementation on the sustainability of Ukraine's development

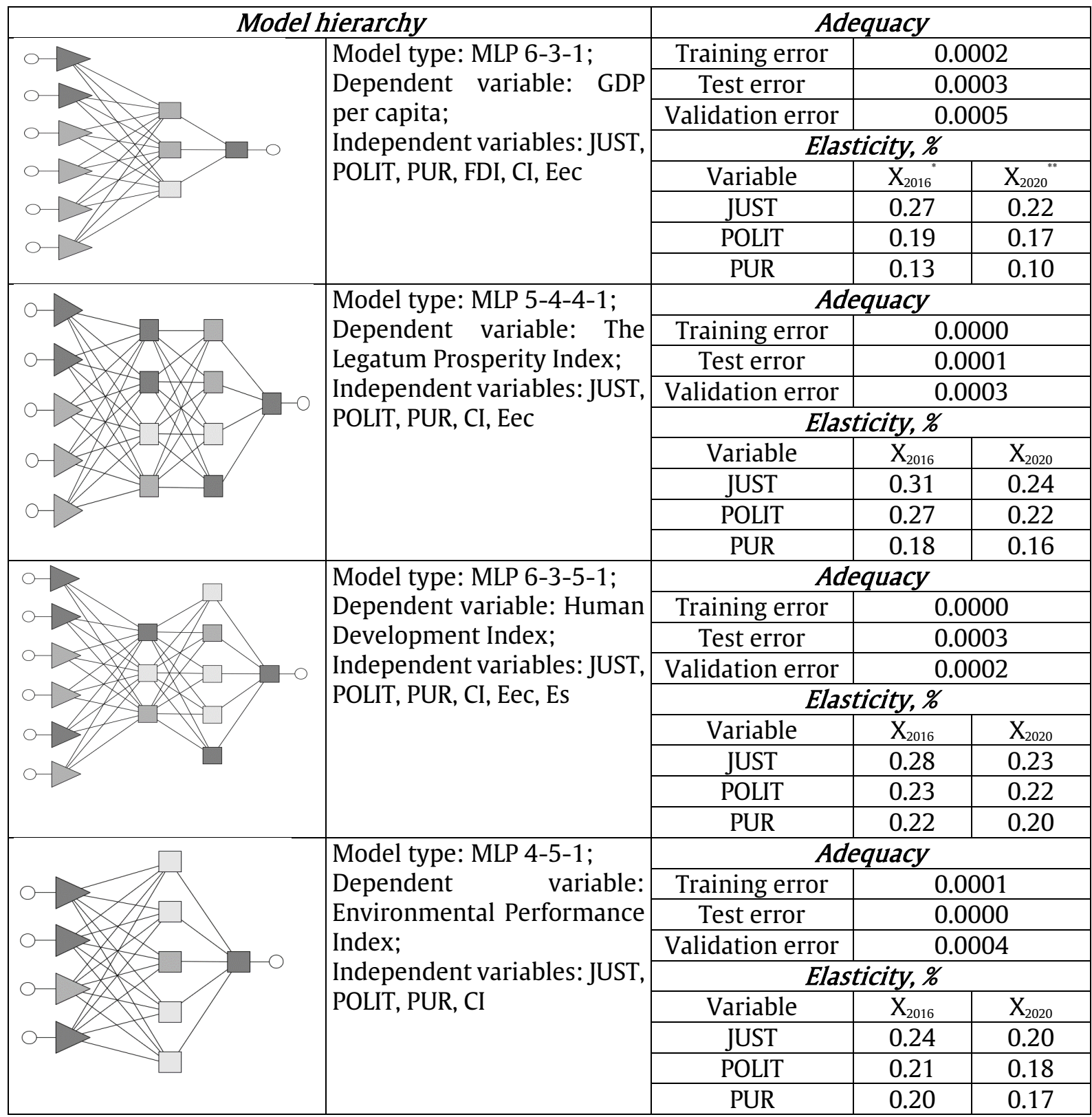

Eec - growth rate of the state budget expenditures on economic;

Es - growth rates of state budget expenditures on social protection and social security;

- elasticity coefficients of change in the resulting indicator with an increase in the corresponding independent variable by $1 \%$ relative to the value for 2016 ;

" - elasticity coefficients of change in the resulting indicator with an increase in the corresponding independent variable by $1 \%$ relative to the value for 2020 г.

Source: Authors' finding

Problems in these areas are priority ones, as which it is impossible to achieve practical cooperation on eurointegration without eliminating them. Problems in these areas primarily relate to: the military conflict in the Donbas and the annexation of Crimea; high 
levels of corruption in Ukraine; the existence of many unsolved crimes committed by police officers, other law enforcement and government officials; unresolved legislative issues of criminalization of smuggling and protection of personal data when using $\mathrm{AI}$; and country discrimination and threats of corruption in the public procurement system. These problems hold back and provoke problems along the lines that formed the 2-5 levels of the hierarchy.

Modeling the prospects for sustainable development as a result of solving the priority problems of the implementation of the $A A$ is presented in Table 1

The adequacy of the constructed models is evidenced by Training, Test, Validation error values not exceeding 5\%. The models included independent variables that are significant at the $\mathrm{p}=0.05$ level.

The elasticity coefficients show the change in the dependent variables, increasing the independent variable by $1 \%$ relative to the values for 2016 and 2020. For all the independent variables that correspond to the directions of $\mathrm{AA}$ implementation, there are positive values of elasticity. This indicates that progress in the implementation of the AA at this stage of development positively impacts the possibilities for the sustainable development of Ukraine. Coefficients of pair correlation between indicators of sustainable development (GDP per capita, The Legatum Prosperity Index, the Human Development Index, and the Environmental Performance Index) and arrows of the progress of the implementation of the AA: (ENER, JUST, TRADE, ENT, POLIT, TAX, EDUC, HUM, AGR, SCIEN, FIN, PUR, SOC, STAT, TRANS, UTIL, PUB.FIN, ENVIR, SANIT, CONS, FRAUD, HEAL, CUST, INTEL) were in the range 0.66-0.84.

\section{DISCUSSION}

\section{Critical areas of the effectiveness of the} implementation of the AA for Ukraine

The models confirmed that the priority problems of implementing the AA are injustice, freedom, security, and human rights; political dialogue, national security, and defense; and public procurement. In addition, the positive values of the elasticity indicators indicate that progress in the implementation of the AA at this stage of development has a positive impact on the possibilities for the sustainable development of Ukraine. Among financing indicators, tsignificant positive impact on sustainable development is provided by the growth rates of capital investments. In the models for assessing the effect on GDP per capita, there are still significant indicators of the growth rates of state budget expenditures on economic activity and foreign direct investment: in the model for assessing the impact on The Legatum Prosperity Index - the growth rate of state budget expenditures on economic activity, and in the model for evaluating the effect on the Human Development Index - the growth rate of the state budget expenditures on economic, social protection and social security.

Although the factors influencing human capital development are education and health care (Our World In Data, 2021; Tsymbalenko, Tarasenko \& Bielialov, 2019), indicators of the dynamics of the volume of public spending are not significant. This can be explained instead by the ineffectiveness of public funds management in these areas. The situation is similar to the indicator of the growth rate of expenses for environmental protection, which is insignificant when assessing the impact on the Environmental Performance Index.

Progress on injustice, freedom, security, and human rights significantly impacts sustainable development indicators. With an increase in overall progress by $1 \%$ relative to 2020 , sustainable development indicators grow by $0.20-0.24 \%$ and result in the highest elasticity coefficients for The Legatum Prosperity Index $(0.24 \%)$ and the Human Development Index (0.23\%).

An increase in overall progress in implementing $A A$ in the field of political dialogue, national security, and defense by $1 \%$ relative to 2020 leads to a rise in GDP per capita by $0.17 \%$, The Legatum Prosperity Index and the Human Development Index by $0.22 \%$, and the Environmental Performance Index by $0.18 \%$.

Progress in implementing the AA in public procurement has a less significant impact on sustainable development opportunities. An increase in sustainable development indicators is possible by $0.10-0.20 \%$, with an increase in overall progress in public procurement by $1 \%$ 
relative to 2020 .

\section{An effective strategy of eurointegration of Ukraine}

Empirically substantiated that at the present stage of socio-economic development, the most effective strategy for the integration process of Ukraine into the EU is the strategy of moderate adaptation. This can be explained by the fact that today the country does not internally meet the standards of the European Union. Homogeneity is a fundamental principle underlying the EU enlargement policy, which means that EU member states are mentally, economically, and politically aligned with current members (European Commission, 2020).

Ukrainian citizens, more than the citizens of European countries, demonstrate a commitment to "security", "conformity", "enrichment", "power", "traditions", and less to such values as "openness to change," "independence," "benevolence" (European Commission, 2020). Ukrainian citizens oscillate between trust and distrust of others. Such uncertainty is in itself an unfavorable social factor. According to the mutual trust of fellow citizens, Ukraine is much inferior to the leading countries of Western Europe and occupies one of the last places in ratings of trust (European Commission, 2020). The state policy of Ukraine should be aimed at encouraging public work and solidarity activity in society, free participation in political and social initiatives, charity, patronage, volunteering, and the performance of representative functions in cases of selforganization, etc.

In terms of adapting the country's economic system, today, the national economy is in a deep crisis and is falling even more profoundly due to the ongoing COVID-19 pandemic. This further exacerbates the gap between Ukraine and Europe. Since it is customary in the EU to bring the economies of new members to the panEuropean level, the inclusion of Ukraine will require an injection of hundreds of billions of dollars, which is disadvantageous for the EU. Therefore, within the framework of moderate adaptation, it seems expedient to urgently modernize the Ukrainian industry. The requirement to introduce international standards for the production of AA is an essential element of this modernization process.
When replacing the current Ukrainian standards, the principle of gradual change must be observed, which can ensure the effectiveness of their implementation in the national economy. Although this process entails significant changes in the practices of many Ukrainian companies, the long-term results will be positive. Since access to the EU market will become much more manageable, companies will become more competitive in world markets.

Politically, Ukraine is not yet ready to participate in the development of collective and responsible pan-European decisions because widespread corruption has reached alarming proportions and continues to hinder the reform process. The country has not achieved a visible result in de-oligarchization; oligarchs continue to exert a strong influence on the Ukrainian economy, politics, judicial system, law enforcement agencies, and the media. The judicial system as an institution has one of the lowest levels of trust in Ukraine (Government portal, 2021). Due to the dominance of various warring factions, Ukraine is mired in extractive institutions. Their social structure gives power to a narrow segment of society, and the rest of the population deprives them of the opportunity to lead an active political life. By creating regular fluctuations in the economic arena, such a device prevents the country from receiving the investment and innovation needed for sustainable development. To improve the situation, the culture of corruption must be eradicated. Success in the fight depends on increased transparency, an independent judiciary, and empowering ordinary citizens to eliminate corrupt politicians (European Commission, 2020).

\section{CONCLUSION}

The positive correlation coefficients in all areas of the implementation of the AA indicate their stimulating and significant impact on the sustainability of the Ukrainian economy. The adaptation of Ukrainian legislation to the EU (which reflects all country's socio-economic development) should be comprehensive (implemented in all areas). But at the same time, there is a decrease in the elasticity indicators with an increase in progress in the implementation of AA. This means that the 
process of rapprochement with the EU should be gradual and accompanied by appropriate state measures to neutralize the risks of European integration, which corresponds to the concept of "moderate adaptation."

Due to the limited quantitative indicators characterizing the degree of implementation of the AA tasks by Ukraine, we used the percentage of their fulfillment among the independent variables. This approach does not allow for the full assessment of the progress of implementation since the content of the tasks of the AA is distinguished by their complexity. Nevertheless, it is possible to assess the effectiveness of the implementation of AA during the tactical performance. In addition, in our further scientific developments, the phased implementation of the strategic tasks of the AA, depending on the level of execution and socioeconomic development of Ukraine, will be investigated. This will allow us to empirically assess complete compliance with a specific strategy for adapting Ukraine to EU standards within the framework of tactical, short-term, and long-term planning for the implementation of the tasks and the effect of their impact on its socio-economic development.

\section{REFERENCES}

Association Agreement between the European Union and Ukraine. (2021). https://www.kmu.gov.ua/en/yevropejskaintegraciya/ugoda-pro-asociacyu

Babenko, V., Biletska, Y., \& Pelyak, H. (2019). Ukraine-EU: economic integration strategy. Geopolitics under Globalization, 3(1), 12-23. https://doi.org/10.21511/gg.03(1).2020.02

Durman, O., Durman, M., Topalova, E., Grytsak, L., \& Zhiliaieva, O. (2021). An economic model to assess the effectiveness of economic cooperation between Ukraine and international non-government organizations. Journal of Eastern European and Central Asian Research, 8(1), 62-80. https://doi.org/10.15549/jeecar.v8i1.640

Eurointegration portal. (2021). Report on Implementation of the Association Agreement Between Ukraine and the European Union 2015-2020. https://euua.kmu.gov.ua/sites/default/files/inline/files /aa_implementation_report_20152020_eng_final.pdf

European Commission. (2020). Joint Staff Working Document. Association Implementation Report on Ukraine. https://eeas.europa.eu/sites/default/files/20 20_ukraine_association_implementation_re port_final.pdf

European Commission. (2021). EU-Ukraine relationship in facts and numbers. https://eeas.europa.eu/sites/default/files/ea p_factsheet_ukraine_ru.pdf

Generic Law on Official Statistics for Eastern Europe, Caucasus, and Central Asia. (2017). https://www.unilibrary.org/content/books/9789210586726? mlang=en

Government portal. (2021). Reports on the implementation of the Association Agreement between Ukraine and the EU. https://www.kmu.gov.ua/diyalnist/yevropej ska-integraciya/vikonannya-ugodi-proasociaciyu/zviti-pro-vikonannya-ugodi-proasociaciyu

Harus, A., \& Nivyevskyi, O. (2020). In Unity, There Is Strength: The Effect of the Decentralization Reform on Local Budgets in Ukraine. https://voxukraine.org/en/in-unitythere-is-strength-the-effect-of-thedecentralization-reform-on-local-budgetsin-ukraine/

Jin, P., Lu, L., Tang, Y., \& Karniadakis, G.E. (2020). Quantifying the generalization error in deep learning in terms of data distribution and neural network smoothness. Neural Networks, 130, 85-99.

Kachala, T., \& Kovalchuk, Y. (2015). Ukrainian Business in European Integration Process: a Cluster Approach. Journal of Eastern European and Central Asian Research, 2(1). https://doi.org/10.15549/jeecar.v2i1.84

Kuzmak, O., Kuzmak, O., \& Pohrishchuk, B. (2021). Sustainable development: trends and realities of Ukraine. Web of Conferences, 255, 01035. https://doi.org/10.1051/e3sconf/202125501 035

Marchak, D., \& Markuts, Y. (2021). Budget Declaration. Second Attempt. 
https://voxukraine.org/en/budgetdeclaration-second-attempt/

Our World In Data. (2021). Human Capital Index vs. GDP per capita.

https://ourworldindata.org/grapher/humancapital-index-vs-gdp

Pisarovi'c, A., Tišma, S., Dujmovíc, K.A., \& Škrtíc, M.M. (2021). The Event of Croatia's EU Accession and Membership from the Croatian High School Students' Perspective. J. Risk Financial Manag., 14, 2. https://dx.doi.org/10.3390/jrfm14010002

Poshedin, O., Palamarchuk, T., \& Gaievska, L. (2020). Milestones vs. Percents: how do we really measure Ukraine's European integration progress? Baltic Journal of Economic Studies, 6(5), 73-82. https://doi.org/10.30525/2256-0742/20206-5-73-82

Razumovskaia, E., Yuzvovich, L., Kniazeva, E., Klimenko, M., \& Shelyakin, V. (2020). The Effectiveness of Russian Government Policy to Support SMEs in the COVID-19 Pandemic. J. Open Innov. Technol. Mark. Complex., 6, 160. https://doi.org/10.3390/joitmc6040160

Schemes against Independence. (2020). https://project.liga.net/projects/corruption_i ndependence/

Shevchuk, S. (2021). Adaptation of the legislation of Ukraine to the legislation of the European Union as a condition of future membership in the EU https://minjust.gov.ua/m/str_52

Spiliopoulos, O. (2014). The EU-Ukraine Association Agreement as a Framework of Integration between the Two Parties. Procedia Economics and Finance, 9, 256263. https://doi.org/10.1016/S22125671(14)00027-6

The Constitution of Ukraine. (2020). Law on June 28, 1996, № 254к/96-BP. https://zakon.rada.gov.ua/laws/show/254\%D 0\%BA/96-\%D0\%B2\%D1\%80?lang=en\#Text

Transparency International. (2020). Corruption Perceptions Index. https://nonews.co/wpcontent/uploads/2021/01/CPI2020.pdf

Tsymbalenko, N.V., Tarasenko, I.O., \& Bielialov, T.E. (2019). The impact of demographic processes on forming student body in
Ukraine. Revista Espacios, 40(12). https://www.revistaespacios.com/a19v40n1 2/a19v40n12p08.pdf

Ukrainian truth. (2021a). More than $60 \%$ of Ukrainians support EU membership, almost 54\% support NATO membership https://www.pravda.com.ua/rus/news/2021 /06/30/7298949/

Ukrainian truth. (2021b). Experts rated Ukraine's cooperation with the EU in 2020 as a four-plus. https://www.pravda.com.ua/rus/news/2021 /04/2/7288764/

YouControl. (2018). On a state needle: which business depends on government procurement? https://youcontrol.com.ua/ru/dataresearch/na-derzhavniy-holtsiyakyy-bizneszalezhyt-vid-derzhzakupivel/

Zanuda, A. (2020). Electricity market reform year: what went wrong. https://www.bbc.com/ukrainian/features53155167 


\section{ABOUT THE AUTHORS}

Olena Durman, email: ol.durman@gmail.com

Olena Durman, Ph.D. in Public Administration, Associate Professor of the Department of Public Administration and Local Government, Kherson National Technical University, Kherson, Ukraine.

Mykola Durman, Doctor of Science in Public Administration, the Honored Worker of Education of Ukraine, Professor of the Department of Public Administration and Local Government, Kherson National Technical University, Kherson, Ukraine.

Tatyana Mazievich, Ph.D. in Economics, Associate Professor of the Department of Land Management, Geodesy and Cadastre, Kherson State Agrarian and Economic University, Kherson, Ukraine

Oksana Zhiliaieva, Postgraduate student of the Department of Parliamentarism of the Educational and Scientific Institute of Public Administration and Civil Service, Taras Shevchenko National University of Kyiv, Kyiv, Ukraine; Senior Lecturer of the Department of Ukrainian Philology and Journalism, Kherson State University, Kherson, Ukraine.

Svitlana Arkhypenko, Ph.D. in Economics, Associate Professor of the Department of Accounting, Taxation, Public Administration, Kryvyi Rih National University, Kryvyi Rih, Ukraine. 